\title{
Synchrony of trend shifts in Sahel boreal summer rainfall and global oceanic evaporation, 1950-2012
}

\author{
Alima Diawara ${ }^{1}$, Yoshihiro Tachibana ${ }^{1}$, Kazuhiro Oshima ${ }^{2}$, Hatsumi Nishikawa ${ }^{1}$, and Yuta Ando ${ }^{1}$ \\ ${ }^{1}$ Weather and Climate Dynamics Division, Mie University, Tsu, Japan \\ ${ }^{2}$ Institute of Arctic Climate and Environment Research, Japan Agency for Marine-Earth Science \\ and Technology, Yokosuka, Japan
}

Correspondence to: Yoshihiro Tachibana (tachi@bio.mie-u.ac.jp)

Received: 2 September 2015 - Published in Hydrol. Earth Syst. Sci. Discuss.: 3 November 2015

Revised: 29 June 2016 - Accepted: 11 July 2016 - Published: 13 September 2016

\begin{abstract}
Between 1950 and 2012, boreal summer (rainy season) rainfall in the Sahel changed from a multi-decadal decreasing trend to an increasing trend (positive trend shift) in the mid-1980s. We found that this trend shift was synchronous with similar trend shifts in global oceanic evaporation and in land precipitation on all continents except the Americas. The trend shift in oceanic evaporation occurred mainly in the Southern Hemisphere (SH) and the subtropical oceans of the Northern Hemisphere (NH). Because increased oceanic evaporation strengthens the atmospheric moisture transport toward land areas, the synchrony of oceanic evaporation and land precipitation is reasonable. Surface scalar winds over the SH oceans also displayed a positive trend shift. Sea surface temperature (SST) displayed a trend shift in the mid-1980s that was negative (increasing, then decreasing) in the SH and positive in the NH. Although SST had opposite trend shifts in both hemispheres, the trend shift in evaporation was positive in both hemispheres. We infer that because strong winds promote evaporative cooling, the trend shift in SH winds strengthened the trend shifts in both SST and evaporation in the SH. Because high SST promotes evaporation, the trend shift in NH SST strengthened the NH trend shift in evaporation. Thus differing oceanic roles in the $\mathrm{SH}$ and $\mathrm{NH}$ generated the positive trend shift in evaporation; however, the details of moisture transport toward the Sahel are still unclear, or perhaps there is no single determining influence.
\end{abstract}

\section{Introduction}

For the past 60 years, the western African Sahel region, located between 10 and $20^{\circ} \mathrm{N}$ longitude, has been one of the most important research areas for studying climatic variability due to its fragile climate conditions. While there are many well-documented analyses of the Sahel's drought conditions since the early 1970s (e.g. Hulme, 1992; Christensen et al., 2007; Baines and Folland, 2007), there is no general explanation of the source of the drought. Several studies have also shown that the Indian Ocean, the North and South Atlantic Ocean, and the Southern Hemisphere ( $\mathrm{SH}$ ) oceans and the Mediterranean Sea have, alone or together, some kind of remote influence on the distribution of Sahel rainfall (Palmer, 1986; Giannini et al., 2003; Wolter, 1989; Janicot et al., 1996; Rowell, 2003; Hagos and Cook, 2008; Diatta and Fink, 2014). Studies and evaluations of the Sahel monsoon are crucial to determine previous precipitation variations, provide climate projections, and offer a scientific response to the decrease in rainfall over the majority of the region (Dai, 2001; Omotosho, 2008); however, the exact linkage between the multi-decadal variations of the Sahel rainfall and the global ocean remain unclear. Sahel rainfall is correlated with remote sea surface temperature (SST), which suggests that globalscale ocean evaporation processes are potentially important for the historical land surface rainfall variability. Our initial analysis suggested that the global hydrological cycle is comprised of evaporation from some part of the ocean surface and the transport of water vapour over the African continent. Therefore, it is reasonable that moisture transport from different parts of the world ocean may, either alone or in combi- 
nation, affect African precipitation in general and that of the Sahel in particular.

Some of the earliest works related to nearby SSTs have shown that precipitation time series have significantly changed over the last 60 years (Lough, 1986; Bader and Latif, 2003; Chung and Ramanathan, 2006). Other studies related to remote SST point out that the precipitation time's series have considerably changed over the past 60 years as well (Folland et al., 1986; Janicot et al., 1996; Rowell, 2003; Fontaine et al., 2011; Munemoto and Tachibana, 2012; Diatta and Fink, 2014). The potential long-term causes and effects of SST variability are important inputs for the thermodynamical process of Sahel rainfall (Folland et al., 1986; Giannini et al., 2003; Tippett and Giannini, 2006; Lu and Delworth, 2005; Hoerling et al., 2006). Although long-term climate trends are commonly related to the state of the ocean, the radiative forcing by changing levels of greenhouse gas and/or aerosols have been considered responsible for the changes in climate in the global ocean and on each continent except Antarctica (Stott et al., 2010). However, the increased trend of the greenhouse gas has not been linked to the trend shift of the Sahel rainfall. Delworth et al. (1993) defined the thermal impacts of the North Atlantic thermohaline overturning flow at multi-decadal scales. Zhang and Delworth (2006) referred to the subsequent SST pattern as the Atlantic Multidecadal Oscillation. Pomposi et al. (2015) examined the role of global SST anomalies and their effects on monsoon variability in the Sahel region and found that "much of the internal variability of the global monsoon system" is generated by SST variances and their outcome on the atmospheric teleconnections, linking oceanic variations to land-based rainfall. Munemoto and Tachibana (2012) demonstrated that the contrast between northern and southern SST also corresponds to the more recent pattern of Sahel rainfall; in the mid-1980s, the phenomenon shifted from a decreasing trend to an increasing trend. These various studies underscore the lack of a single mechanism determining the relationship between the shift of the Sahel rainfall and the shift of oceanic evaporation. Folland et al. (1986) were among the first to historically establish a relationship between Sahel rainfall and (SH) SST on multi-decadal timescales; the relationship has demonstrated that when the SH SST is higher (lower) than normal, the Sahel is drier (wetter) than normal (Folland et al., 1986). Bader and Latif (2003) considered the warming trend in the Indian Ocean to have "a crucial role for the [40-year] drying trend over the West Sahel". As a consequence, Indian Ocean warming may have contributed to the strengthening of the North Atlantic Oscillation during these last 2 decades. In addition, their experiments highlight the influence of the tropical Pacific over the eastern Sahel, whereas the tropical Atlantic influences rainfall only over the Atlantic itself and along the western Sahel.

For this study, we analysed global evaporation data sets for the second half of the 20th century in order to determine whether the previously established linkages between remote
SST and Sahel rainfall are the result of remote linkages between Sahel rainfall and oceanic evaporation. We also investigated the underlying trends in wind stress and SST that may explain changes in evaporation. Given the region's exposure to natural variability, favouring severe drought with unexplained sequence variations, this study will deliver a skillful multi-decadal climate forecast for the Sahel.

\section{Data and methods}

For the precipitation, we used three different monthly data sets: from 1949 to 2014, the National Oceanic and Atmospheric Administration (NOAA) Precipitation Reconstruction over Land (PREC/L) database (Chen et al., 2002) with a spatial resolution of $1.0^{\circ}$ in latitude and longitude; the Global Precipitation Climatology Centre (GPCC) data (Schneider et al., 2011), $2.5 \times 2.5^{\circ}$, from 1949 to 2013 ; and the University of Delaware UDel_AirT_Precip data provided by the NOAA/OAR/ESRL PSD, Boulder, Colorado, USA, from their website at http://www.esrl.noaa.gov/psd/, resolution of $0.5 \times 0.5^{\circ}$ and from 1949 to 2013 . For SST, we used monthly data from 1953 to 2012 in the NOAA Extended Reconstructed SST Version 3 (NOAA ERSST V3) data set, which is constructed from SST data in the International Comprehensive Ocean-Atmosphere Data Set (ICOADS) (Smith et al., 2008; Xue et al., 2003). Monthly $10 \mathrm{~m}$ scalar wind speed data from 1950 to 2011 came from Wave and Anemometerbased Sea Surface Wind (WASWind) version 1.0.1 (Tokinaga and Xie, 2011), derived from ship observations in ICOADS and presented at a resolution of $4 \times 4^{\circ}$. Specific humidity data at $2^{\circ}$ resolution were from ICOADS. Both wind speed and specific humidity databases have missing values in areas outside shipping routes, especially at high latitudes. Because Chiu et al. (2012) view oceanic evaporation, or sea surface latent heat flux (LHF) divided by the latent heat of vaporization $(\mathrm{Lv})$, as a crucial factor in the global water and energy cycle, we used LHF data for 1950-2012 from the National Centers for Environmental Prediction/National Center for Atmospheric Research (NCEP/NCAR) Reanalysis (Kalnay et al., 1996) as a fundamental proxy for oceanic evaporation. We also used data from the Japanese Re-Analysis 55 Years (JRA55) (Kobayashi et al., 2015) and the European Centre for Medium-Range Weather Forecasts (ECMWF) 40-year Reanalysis (ERA-40) (Uppala et al., 2005) data sets and compared these data sets to the LHF data from NCEP/NCAR and the moisture flux vector. Based on the comparison, we addressed possible reliability problems in moisture data from the pre-satellite era. Although there are some differences between these three databases, the differences do not significantly influence our conclusions. Our analysis primarily used July-August-September (JAS) averages, corresponding to the Sahel region's rainy season.

Figure 1 shows the long-term value of JAS average precipitation in northern Africa using PREC_L data. Our study 


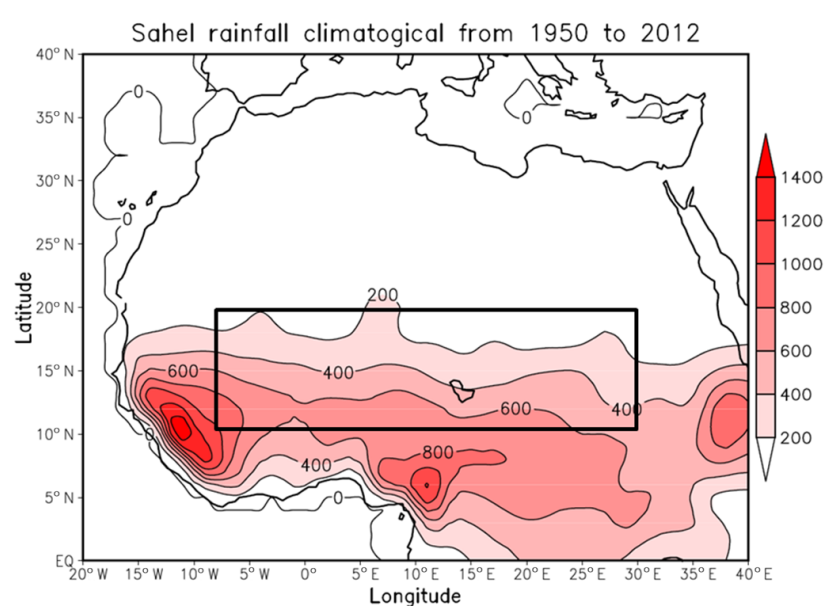

Figure 1. Climatological JAS mean of northern African regional rainfall averaged from 1950 to 2012. The area defined as the Sahel region is in the rectangle between latitude $10-20^{\circ} \mathrm{N}$ and longitude $8^{\circ} \mathrm{W}-30^{\circ} \mathrm{E}$. The unit is $\mathrm{mm}$.

area, defined as the region bounded by $10-20^{\circ} \mathrm{N}$ and $8^{\circ} \mathrm{W}-$ $30^{\circ} \mathrm{E}$, was chosen to avoid coastal influences on seasonal rainfall in the Sahel. The JAS has captured, by definition, the Sahel region rainy season between 200 and $600 \mathrm{~mm}$ per JAS per year, and we used the PREC_L data for the smooth resolution of the data. Figure 2 shows the variation of JAS average rainfall in the study area from 1950 through to 2012 . Sahel rainfall decreased from the early 1960s to the mid1980s, followed by an increasing trend for the rest of the study period. The driest year of the study period was 1984 (Munemoto and Tachibana, 2012); we focused on that period to divide our data set into two different periods, the decreasing and increasing periods. The mid-1980s mark a clear reversal in these multi-decadal trends. The signature of this trend shift is not sensitive to the definition of the study area (results not shown). Because the data were insufficient to analyse at least two cycles of multi-decadal variability, we focused on a phenomenon ("the trend shift") that might indicate a phase change.

To assess the degree to which trends in other climatic parameters synchronized with the Sahel trend shift, we divided the time series of all data sets into the subperiods 1950-1984 and 1985-2012. We defined the trend in each subperiod as the angle of inclination, $\tan \theta$, of the time series, as calculated from the linear regression coefficient using the least squares method. We defined the strength of the trend shift, $\delta \tan \theta$, as $\tan \theta_{2}-\tan \theta_{1}$, where subscripts 1 and 2 denote the subperiods before and after 1984, respectively. To confirm that the trends of the two subperiods differed in sign, we added the condition $\tan \theta_{1} \cdot \tan \theta_{2}<0$. We named a decreasing to increasing (increasing to decreasing) trend shift as a positive (negative) trend shift, i.e. $\delta \tan \theta>0(\delta \tan \theta<0)$ and $\tan \theta_{1} \cdot \tan \theta_{2}<0$.

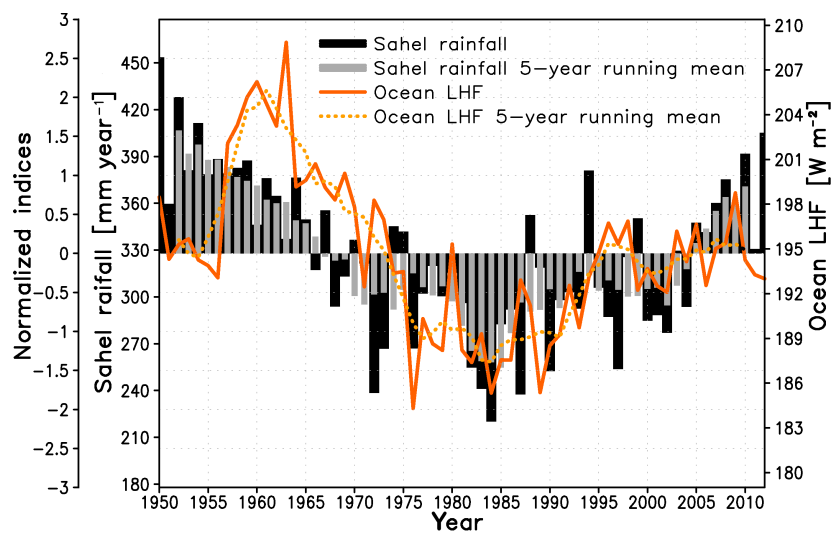

Figure 2. Time series of JAS Sahel rainfall $(\mathrm{mm})$ and mean LHF $\left(\mathrm{W} \mathrm{m}^{-2}\right.$ ) from oceans from 1950 to 2012.

\section{Results}

\subsection{Trend shifts of Sahel precipitation and ocean evaporation}

The time series of the global JAS mean LHF decreased before the mid-1980s, followed by an increase (Fig. 2). Although this increase ceased after the mid-1990s, the turning point of the trend shift coincided with Sahel rainfall. Global annual mean LHF also had a similar trend shift to that of the JAS mean (Li et al., 2011). This synchrony suggests that, at the multi-decadal timescale, the variability of Sahel rainfall may be physically linked to the transport of the moisture flux from the oceans. We also investigated global mean sensible heat flux, but found no significant trends during the study period.

The trend shift in LHF in the world ocean may be related to precipitation inside and outside the Sahel. The results of our investigation of this possibility are shown for both JAS and annual precipitation of PREC_L in Fig. 3a and b, respectively. The trend shift over the Sahel is stronger for annual precipitation than for JAS precipitation. The areas where the positive trend shifts (from decreasing to increasing) in JAS precipitation are large are the Sahel, western coastal areas of South Asia, and equatorial South America (Fig. 3a).

For annual precipitation, the areas with positive trend shifts are more numerous than the areas with negative trend shifts (Fig. 3b). Positive trend shifts are particularly strong in the Sahel, western coastal areas of South Asia, and southern Chile, and less strong in Korea, Japan, the Philippines, Alaska, and northern Eurasia. Negative trend shifts are seen in South America, most of the SH, most of North America, and inland Eurasia; these areas are weaker and narrower than the areas with a positive trend shift. These results indicate that a positive trend shift in precipitation occurred not only in the Sahel, but also elsewhere in the world. Comparing the trend shifts of JAS precipitation of the PREC_L (Fig. 3a), GPCC (Fig. 3c), and University of Delaware (Fig. 3d) data 
(a) JAS-PREC_L

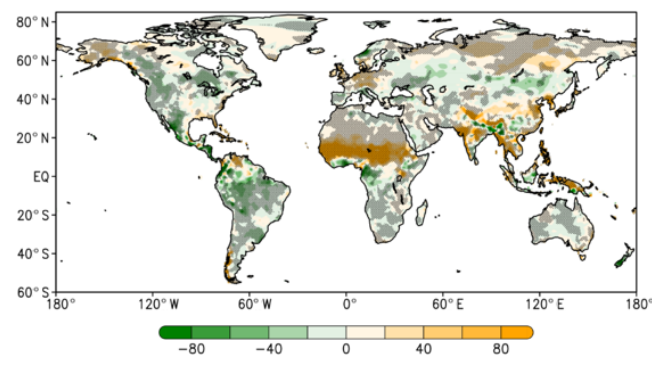

(b) Annual-PREC_L

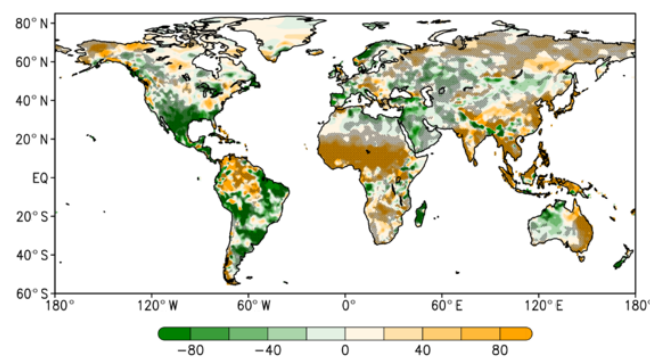

(c) JAS-GPCC

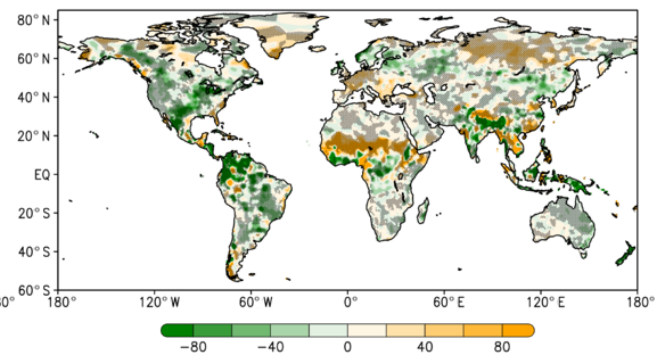

(d) JAS-University of Delaware

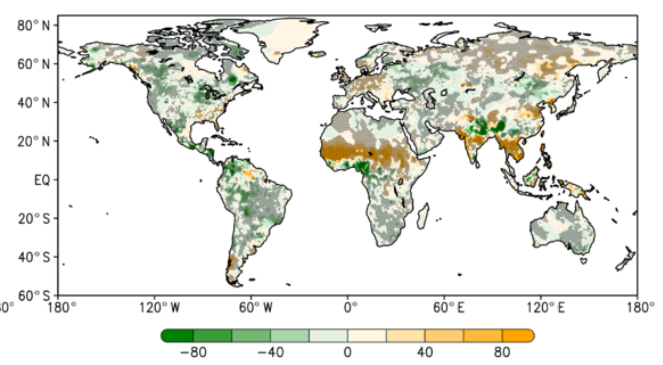

Figure 3. Global maps of the trend shift for (a) JAS precipitation PREC_L (mm 10 years ${ }^{-1}$ ), (b) annual precipitation, (c) JAS precipitation GPCC, and (d) JAS precipitation - University of Delaware. Shading denotes $\delta \tan \theta$. Hatching represents areas where trends changed sign between the two parts of the study period $\left(\tan \theta_{1} \cdot \tan \theta_{2}<0\right)$.

sets, similar land coverage was observed, with a correlation of 0.9; however, the University of Delaware (Fig. 3d) data set showed a weaker signal over the same areas included in the PREC_L and GPCC data sets.

\subsection{Global SST trend shift}

Sahel rainfall is related to nearby SST (Lough, 1986; Bader and Latif, 2003; Chung and Ramanathan, 2006) and remote SST (Folland et al., 1986; Janicot et al., 1996; Rowell, 2003; Fontaine et al., 2011; Munemoto and Tachibana, 2012; Diatta and Fink, 2014). Although there is no visible evidence of change, it is conceivable that the SST time series has a changing phase from 1984 using the SST over the Northern Hemisphere (NH) and SH. As demonstrated by Munemoto and Tachibana (2012), the NH SST became lower than that of the SH SST and described an opposite trend after 1984. Figure 4 shows that areas of positive trend shift in the JAS SST over the oceans are widespread in the $\mathrm{NH}$, meaning that SST decreased until 1984 and then increased. Areas of negative trend shift are mostly in the $\mathrm{SH}$, particularly the eastern tropical Pacific and the South Atlantic Ocean. The obvious contrast between hemispheres suggests that the change in JAS Sahel rainfall is somehow related to the hemispheric contrast in SST; these results are consistent with the findings of Folland et al. (1986) and Munemoto and Tachibana (2012). In addition, modelling and observational studies by Bader and Latif (2003) show that the Sahel region rainfall variability is

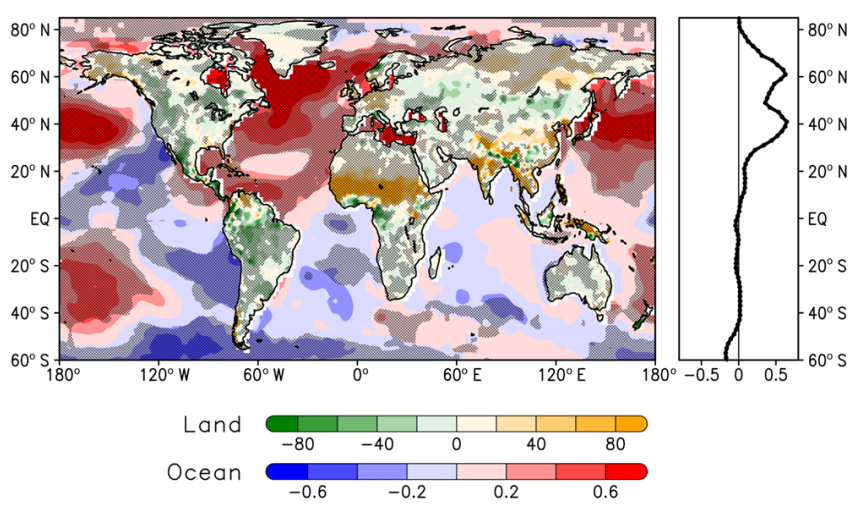

Figure 4. (Left) trend shifts in SST (K 10 years $^{-1}$ ) and (right) latitude profile of its zonal mean. Land areas display trend shifts in JAS precipitation from Fig. 3a. Hatching represents areas where trends changed sign between the two parts of the study period $\left(\tan \theta_{1} \cdot \tan \theta_{2}<0\right)$.

linked with regional and global SST anomaly patterns, which include fluctuations in the tropical Atlantic Ocean, as pointed out by Lamb (1978), Hastenrath (1984), and Lamb and Peppler (1992); the Pacific Ocean, as alluded to by Janicot et al. (1996) and Rowell (2001); the Indian Ocean, as referred to by Palmer (1986) and Shinoda and Kawamura (1994); and the Mediterranean, as mentioned by Rowell (2003). 


\subsection{Trend shift of global ocean evaporation}

The time change in the SST, i.e. the SST trend, should be linearly related to the evaporation from the ocean provided that the ocean is treated as a slab. The time change in the evaporation, i.e. the LHF trend, should thus be linearly related to the second-order differential of the SST. Here we simply compare between the two trend shifts, because the quality of the global data set does not resolve the second-order differential. Figure 5a and b show the JAS trend shift's geographic distribution of land water vapour flux and global ocean evaporation, as defined by LHF using NCEP and JRA-55 data, respectively. They both show similar signs over the oceans, except at the coastline of western South America and the tropical Atlantic; one possible explanation is that the JRA-55 data are missing at least 10 years before 1984, which could capture the tropical Atlantic magnitude. When the subtropical $\mathrm{SH}$ Atlantic Ocean is warmer (colder) than normal, greater (lesser) LHF production is observed, with a deeper surface coverage of the moisture flux transient through the western coast of the Sahel region, whereas the NCEP data show a coverage transient through the eastern Sahel coast; similar results were found by Bader and Latif (2003). The NCEP and JRA-55 data sets captured a significant relation over the Sahel region, even though the JRA-55 evaporation rate increases at the western side of the Sahel region and is negative in the eastern part. The relationship of the tropical Pacific Ocean, El Niño, and both the North and South Atlantic with the Sahel's rainfall variation, which was confirmed by Zhang and Delworth (2006), is observed in the JRA-55 data but not in the NCEP/NCAR data.

\subsection{Trend shifts of wind and humidity}

Latent heat flux is determined by surface wind speed and the humidity deficit over the ocean. Displayed in Fig. 6 is the trend shift of JAS surface scalar wind speeds over the ocean. This shift is positive over most of the SH, particularly in the eastern Pacific Ocean. Many of these positive areas match areas with positive LHF trend shifts (Fig. 5). In the NH, the trend shift is positive over the subtropical central and eastern Pacific. Over the western subtropical North Atlantic Ocean, the trend shift in the scalar wind is not in agreement with the trend shift in LHF; nevertheless, the overall similarity of Figs. 6 and 5 signifies that trend shifts in wind speed over the ocean partially account for the trend shift in LHF.

The trend shift in the JAS deficit of surface-specific humidity, as determined from its saturated value at the local SST, is shown in Fig. 7. The geographic distribution of this positive trend shift is essentially global, similar to those of SST (Fig. 4) and LHF (Fig. 5) in the NH and the southern Pacific Ocean. The positive trend shift of global evaporation from the ocean is therefore also partially explained by this trend shift.
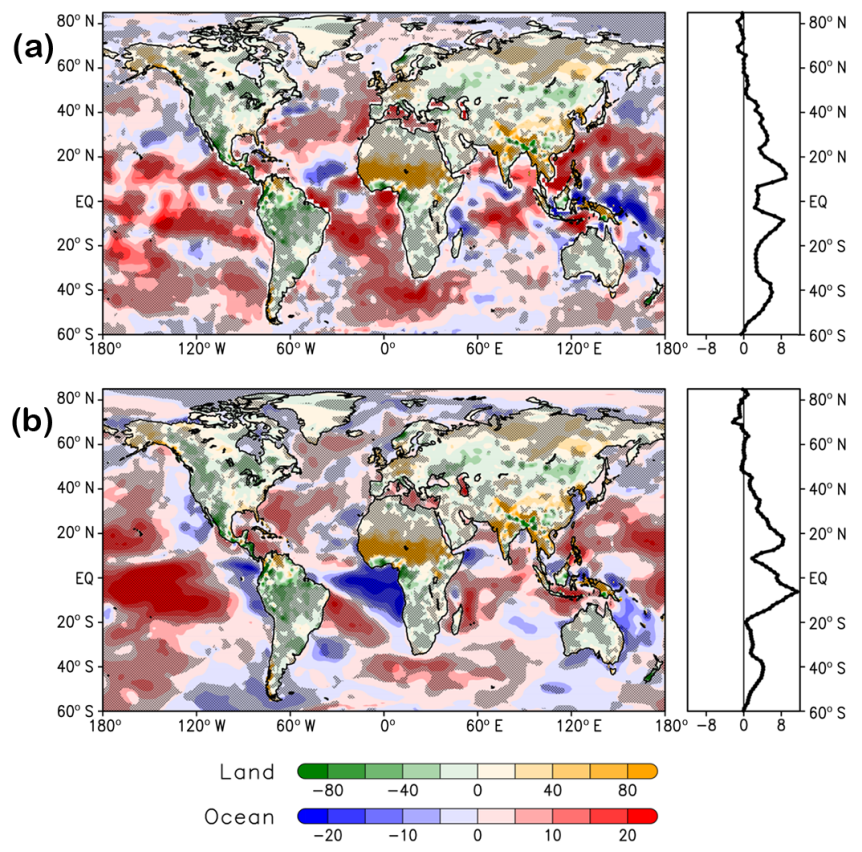

Figure 5. Global maps of the LHF trend shift over the oceans for (a) JAS-NCEP $\left(\mathrm{W} \mathrm{m}^{-2} 10\right.$ years $\left.^{-1}\right)$ and (b) JAS-JRA55. Land areas display trend shifts in JAS precipitation from Fig. 3a. Shading denotes $\delta \tan \theta$. Hatching represents areas where trends changed sign between the two parts of the study period $\left(\tan \theta_{1} \cdot \tan \theta_{2}<0\right)$.

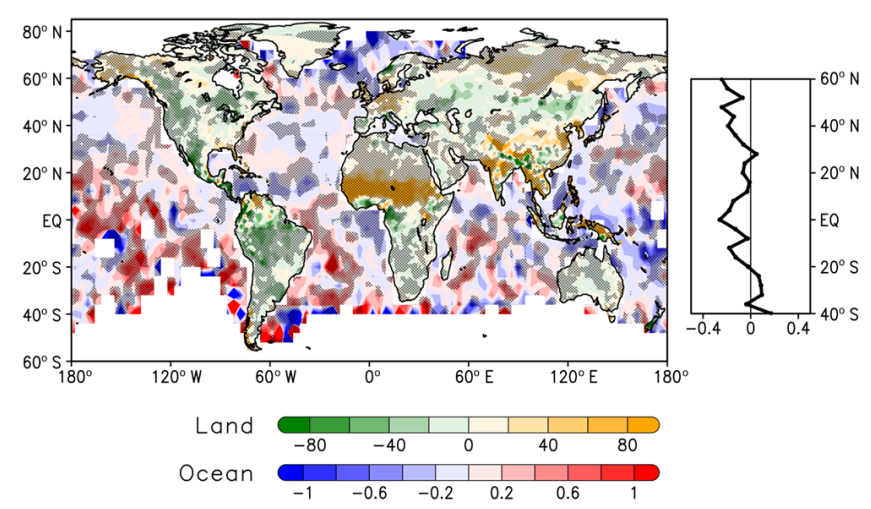

Figure 6. (Left) trend shifts in scalar wind speed over the ocean $\left(\mathrm{m} \mathrm{s}^{-1} 10\right.$ years $\left.^{-1}\right)$ and (right) latitude profile of its zonal mean. Land areas display trend shifts in JAS precipitation from Fig. 3a. Hatching represents areas where trends changed sign between the two parts of the study period $\left(\tan \theta_{1} \cdot \tan \theta_{2}<0\right)$.

Figure 8 shows a map of the JAS moisture flux trend shift using JRA-55. In this figure we can observe an anticyclonic curvature from the eastern tropical Pacific toward the tropical Atlantic and eastward flux from the tropical Atlantic to the Sahel region; the flux from the Indian Ocean at about $40^{\circ} \mathrm{S}$ through to the South Atlantic Ocean is also witnessed. This flux is furthermore connected to the tropical Atlantic Ocean. Most importantly, this figure clearly highlights the key role 


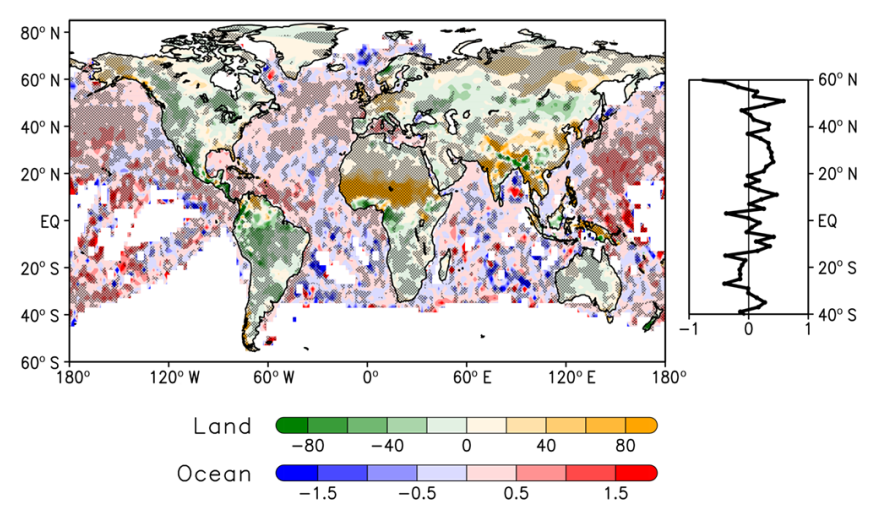

Figure 7. (Left) trend shifts in the humidity deficit $\left(\mathrm{g} \mathrm{kg}^{-1} 10\right.$ years $\left.{ }^{-1}\right)$ over the ocean and (right) latitude profile of its zonal mean. Land areas display trend shifts in JAS precipitation from Fig. 3a. Hatching represents areas where trends changed sign between the two parts of the study period $\left(\tan \theta_{1} \cdot \tan \theta_{2}<0\right)$.

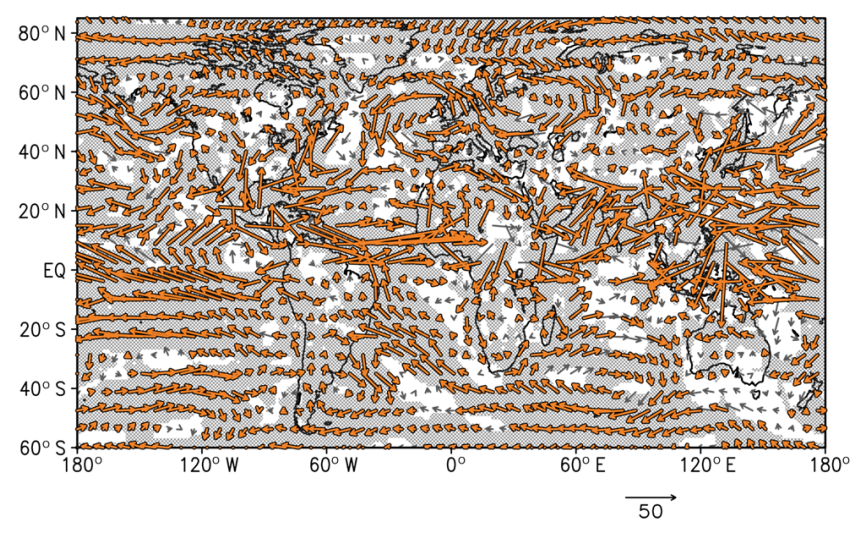

Figure 8. Trend shift vector map of moisture flux using JRA-55 $\left(\mathrm{kg} \mathrm{m}^{-1} \mathrm{~s}^{-1} 10\right.$ years $\left.^{-1}\right)(1958-2014$ : JAS $)$. The orange bold vector and hatching represent areas where northward or eastward moisture flux trends changed sign between the two parts of the study period $\left(\tan \theta_{1} \cdot \tan \theta_{2}<0\right)$.

the southern Indian Ocean and the eastern Pacific Ocean play in Sahel rainfall variation. In addition, weaker transport from the North Atlantic through to the Mediterranean Ocean entrance to Libya is also observed; however, this phenomenon is blocked by the local high pressure located in the Sahara.

\section{Discussion and conclusion}

Our study demonstrates an important synchrony between Sahel rainfall and global evaporation from oceans. The key point is that the shift in the trend of JAS Sahel rainfall from decreasing to increasing (positive trend shift) occurred in the mid-1980s and coincided with shifts in global-scale SST and evaporation from the oceans (Table 1). We found that the Sahel trend shift was synchronous with similar positive trend shifts in global oceanic evaporation (Fig. 2) and in land precipitation outside the Sahel, except in the Americas (Fig. 3). In detail, the trend shift in oceanic evaporation (as indicated by LHF) encompassed the SH and the subtropical NH, including the Pacific, Atlantic, and Indian oceans (Fig. 5). Because increased oceanic evaporation strengthens global moisture transport toward the land, the synchronization of these trend shifts is physically plausible, and indeed the area of increased LHF exceeded the area of decreased LHF. Trend shifts also occurred in the mid-1980s in SST: the shift was negative (increase to decrease) in the SH and positive in the $\mathrm{NH}$, giving rise to an interhemispheric contrast in SST (Fig. 4). The surface scalar wind over the ocean had a positive trend shift, mainly in the $\mathrm{SH}$, that extended to the subtropical Pacific Ocean in the NH (Fig. 6). The humidity deficit displayed a positive trend shift in both hemispheres, particularly in the Pacific Ocean (Fig. 7). The strongest statement comes from the vector moisture flux, which clearly represents the path of the moisture flux from the eastern Pacific and southern Indian oceans through to the tropical southern Atlantic to the western entrance of the Sahel region, and also the tropical northern Atlantic through to northern Europe and through to Libya as an entrance that was, however, dissipated by the blocked high pressure in the Sahara region (Fig. 8). The eastern Pacific and southern Indian oceans are the areas where the positive trend shift of the latent heat flux is observed (Fig. 5).

From these results, we can assert that the process that connects the trend shifts of the global oceans and Sahel rainfall is summarized in Fig. 9, which is the main reason for the positive trend shift in LHF, is the positive trend shift in scalar wind, particularly in the SH, because surface wind promotes evaporation from the ocean. When SST is greater than normal, the atmosphere becomes unstable, leading to an interaction between convection and large-scale circulation that strengthens the convergence at the surface with a low wind speed at this centre, generating a small amount of LHF. LHF lowers the SST due to evaporative cooling, which was also suggested by Wu et al. (2009) and Zhang and Mcphaden (1995). Therefore, the negative trend shift in SH SST may be an effect of the positive trend shift in the scalar wind. Giannini et al. (2003) and Zeng (2003) demonstrated that in the $\mathrm{SH}$, when the gulf is warm, the Intertropical Convergence Zone (ITCZ) shifts south away from the Sahel, reducing the African monsoon that draws moist air into the Sahel, which means that long-term changes in Sahel rainfall are induced by changes in SST in the tropical Atlantic and Pacific oceans. The opposite way is that the advection of the magnitude of the moisture flux from the oceans toward the Sahel region forces the ITCZ to shift northward toward the Sahel region during the boreal summer. Although the linkages can be viewed as speculative and conceptual, the phenomenon could explain why both hemispheres are correlated positively, even though their SSTs are different. 
Table 1. Summary of results for JAS meteorological parameters. "Positive" indicates that a shift from decrease to increase occurred during 1950 to 2012; "negative" indicates a shift from increase to decrease.

\begin{tabular}{llllll}
\hline & Sahel rain & SST & LHF & Wind & Humidity deficit \\
\hline Northern Hemisphere & Positive & Positive & Positive & $\begin{array}{l}\text { Positive } \\
\text { (tropical Pacific) }\end{array}$ & Positive \\
\hline Southern Hemisphere & & Negative & Positive & Positive & $\begin{array}{l}\text { Positive } \\
\text { (Pacific) }\end{array}$
\end{tabular}

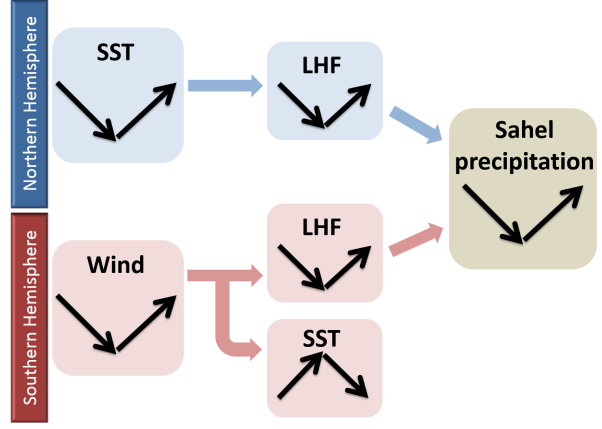

Figure 9. Schematic diagram of possible processes linking Sahel precipitation and the global ocean. The arrows represent increases or decreases in a parameter during 1950-1984 and 1985-2012.

In the $\mathrm{NH}$, at latitudes lower than $40^{\circ} \mathrm{N}$, the LHF trend shift tended to be positive, in synchrony with the positive SST trend shift. Because high SST at low latitudes generally promotes evaporation, the positive trend shift in LHF may be a consequence of the positive trend shift in SST; the positive trend shift in the humidity deficit in the $\mathrm{NH}$ also supports this inference. Thus, the positive SST trend shift in the NH may be linked to the positive LHF trend shift. Although the trend shift in SST is positive in the NH and negative in the $\mathrm{SH}$, hemispheric differences in the role of SST may result in a global positive trend shift in LHF.

Although our study offers an explanation for these globalscale trend shifts, the reason for the outsized signature of Sahel rainfall is still problematic. In line with our viewpoint, Pomposi et al. (2015) affirmed that "understanding of how the monsoon reacts to global SSTs remains incomplete because the system can be impacted by moisture availability locally and in the region as well as tropical atmospheric stability, both of which are influenced by ocean temperatures". In the past, the influence of SST in different remote sites was emphasized (Folland et al., 1986; Czaja and Frankignoul, 2002; Dijkstra, 2006; Ting et al., 2009), including in the Atlantic Ocean (Hu and Huang, 2006; Marullo et al., 2011; Martin et al., 2014), Pacific Ocean (Rowntree, 1972; Pan and Oort, 1983; Cayan and Peterson, 1989; Wallace et al., 1989), and Indian Ocean (Clemens et al., 1991; Ashok et al., 2001, 2003; Annamalai et al., 2005). To identify how evaporation in these remote oceans drives Sahel rainfall, idealized atmo- spheric general circulation model studies will need to incorporate the anomalous SST patterns shown in this study. The processes underlying the trend shift in the ocean surface wind must also be identified. Additionally, it is noteworthy that the trend shift in oceanic evaporation might affect the global salinity distribution, and in turn the global thermohaline circulation. Remarkably, the SST-Sahel teleconnection seems to be stronger with the Indian Ocean (negative correlation) and Mediterranean index (positive correlation) in about 50\% of the years of that era (Fontaine et al., 2011), which led us to conclude that the resemblance between global trends and trends in the Sahel makes it difficult to attribute changes in the Sahel to only a single teleconnection. Largely, the horizontal transfer of heat flux from oceans to the Sahel region through precipitation variability (or opposite) has been highlighted.

Furthermore, our experiments confirm the hypothesis that the southern Indian Ocean, eastern Pacific Ocean, and Atlantic Ocean significantly influence not only regional climate anomalies, as Bader and Latif (2003) suggested, but also the relationship between global changes in SSTs and the Sahel region's rainfall variability, as revealed by Folland et al. (1986). The conclusion, which one can draw from these various studies, is that the Sahel constitutes the world's largest area in which this trend shift occurred. Rainfall or dry conditions in the western African Sahel region can definitely be associated with the role of the global oceans.

\section{Data availability}

For the precipitation, we used the National Oceanic and Atmospheric Administration (NOAA) Precipitation Reconstruction over Land (PREC/L) database (Chen et al., 2002), the Global Precipitation Climatology Centre (GPCC) data (Schneider et al., 2011), and the University of Delaware UDel_AirT_Precip data provided by the NOAA/OAR/ESRL PSD, Boulder, Colorado, USA, from http://climate.geog.udel.edu/ climate/ html_pages/README.ghcn_ts2.html (Willmott and Matsuura, 2001), resolution. For SST, we used monthly data from 1953 to 2012 in the NOAA Extended Reconstructed SST Version 3 (NOAA ERSSTV3)in the International Comprehensive Ocean-Atmosphere Data Set (ICOADS) (Smith et 
al., 2008; Xue et al., 2003). For scalar wind speed data, we used Wave and Anemometer-based Sea Surface Wind (WASWind) version 1.0.1 (Tokinaga and Xie, 2011). For Specific humidity data, we used ICOADS For LHF data, we used National Center for Environmental Prediction/National Center for Atmospheric Research (NCEP/NCAR) Reanalysis (Kalnay et al., 1996). We also used data from the Japanese Re-Analysis 55 Years (JRA-55) (Kobayashi et al., 2015) and the European Centre for Medium-Range Weather Forecasts (ECMWF) 40-year Reanalysis (ERA-40) (Uppala et al., 2005).

Acknowledgements. We thank the Ministry of Education, Culture, Sports, Science and Technology (MEXT) for the opportunity afforded by the international student scholarship programme. MEXT supported this study through a Grant-in-Aid for Scientific Research on Innovative Areas (grant number 22106003). We extend special thanks to Kunihiko Kodera, Koji Yamazaki, and Nicholas Heavens for insightful discussions. We also thank the editor and anonymous reviewers for their valuable comments and suggestions to improve the quality of the paper. The Grid Analysis and Display System (GrADS) and Generic Mapping Tools (GMT) were used to draw the figures.

Edited by: A. Guadagnini

Reviewed by: two anonymous referees

\section{References}

Annamalai, H., Liu, P., and Xie, S. P.: Southwest Indian Ocean SST Variability Its Local Effect and Remote Influence on Asian Monsoons, J. Climate, 18, 4150-4167, doi:10.1175/JCLI3533.1, 2005.

Ashok, K., Guan, Z., and Yamagata, T.: Impact of the Indian Ocean dipole on the relationship between the Indian Monsoon rainfall and ENSO, Geophys. Res. Lett., 28, 4499-4502, doi:10.1029/2001GL013294, 2001.

Ashok, K., Guan, Z., and Yamagata, T.: Influence of the Indian Ocean Dipole on the Australian winter rainfall, Geophys. Res. Lett., 30, 1821-1825, doi:10.1029/2003GL017926, 2003.

Bader, J. and Latif, M.: The impact of decadal-scale Indian Ocean sea surface temperature anomalies on Sahelian rainfall and the North Atlantic Oscillation, Geophys. Res. Lett., 30, 2169-2172, doi:10.1029/2003GL018426, 2003.

Baines, P. G. and Folland, C. K.: Evidence for rapid global climate shift across the late 1960s, J. Climate, 20, 2721-2744, doi:10.1175/JCLI4177.1, 2007.

Cayan, D. R. and Peterson, D. H.: The Influence of North Pacific Atmospheric Circulation on Streamflow in the West, in Aspects of Climate Variability in the Pacific and the Western Americas, Geophys. Monogr., No. 55, Amer. Geophys. Union, 375-397, doi:10.1029/GM055p0375, 1989.

Chen, M., Xie, P., Janowiak, J. E., and Arkin, P. A.: Global Land Precipitation: A 50-yr Monthly Analysis Based on Gauge Observations, J. Hydrometeor., 3, 249-266, doi:10.1175/15257541(2002)003<0249:GLPAYM>2.0.CO;2, 2002 (data available at: http://www.esrl.noaa.gov/psd/data/gridded/data.precl.html).
Chiu, L. S., Gao, S., and Shie, C.-L.: Oceanic evaporation: Trends and variations, Remote Sensing, Book 2, 261-278, InTech Open Access Publisher, 2012.

Christensen, J. H., Hewitson, B., Busuioc, A., Chen, A., Gao, X. Held, I., Jones, R., Kolli, R. K., Kwon, W.-T., Laprise, R., Rueda, V. M., Mearns, L., Menéndez, C. G., Räisänen, J., Rinke, A., Sarr, A., and Whetton, P.: Regional Climate Projections, in: Climate Change 2007: The Physical Science Basis. Contribution of Working Group I to the Fourth Assessment Report of the Intergovernmental Panel on Climate Change, edited by: Solomon, S., Qin, D., Manning, M., Chen, Z., Marquis, M., Averyt, K. B., Tignor, M., and Miller, H. L., Cambridge University Press, Cambridge, United Kingdom and New York, NY, USA, 2007.

Chung, C. E. and Ramanathan, V.: Weakening of North Indian SST Gradients and the Monsoon Rainfall in India and the Sahel, J. Climate, 19, 2036-2045, doi:10.1175/JCLI3820.1, 2006.

Clemens, S., Prell, W., Murray, D., Shimmield, G., and Weedon, G.: Forcing mechanisms of the Indian Ocean monsoon, Nature, 353, 720-725, doi:10.1038/353720a0, 1991.

Czaja, A. and Frankignoul, C.: Observed Impact of Atlantic SST Anomalies on the North Atlantic Oscillation, J. Climate, 15, 606-623, doi:10.1029/2004JD005676, 2002.

Dai, A.: Drought under global warming: a review, WIREs Climate Change, 2, 45-65, doi:10.1002/wcc.81, 2011.

Delworth, T. L., Manabe, S., and Stouffer, R. J.: Interdecadal variations of the thermohaline circulation in a coupled oceanatmosphere model, J. Climate, 6, 1993-2010, doi:10.1175/15200442(1993)006<1993:IVOTTC>2.0.CO;2, 1993.

Diatta, S. and Fink, A. H.: Statistical relationship between remote climate indices and West African monsoon variability, Int. J. Climatol., 34, 3348-3367, doi:10.1002/joc.3912, 2014.

Dijkstra, H. A.: Interaction of SST Modes in the North Atlantic Ocean, J. Phys. Oceanogr., 36, 286-299, doi:10.1175/JPO2851.1, 2006.

Folland, C. K., Palmer, T. N., and Parker, D. E.: Sahel rainfall and worldwide sea temperatures, 1901-85, Nature, 320, 602-607, doi:10.1038/320602a0, 1986.

Fontaine, B., Gaetani, M., Ullmann, A., and Roucou, P.: Time evolution of observed July-September sea surface temperature-Sahel climate teleconnection with removed quasiglobal effect (1900-2008), J. Geophys. Res., 116, D04105, doi:10.1029/2010JD014843, 2011.

Giannini, A., Saravanan, R., and Chang, P.: Oceanic forcing of Sahel rainfall on annually to interdecadal time scales, Science, 302, 1027-1030, doi:10.1126/science.1089357, 2003.

Hagos, S. M. and Cook, K. H.: Ocean Warming and Late-TwentiethCentury Sahel Drought and Recovery, J. Climate, 21, 37973814, doi:10.1175/2008JCLI2055.1, 2008.

Hastenrath, S.: Interannual Variability and Annual Cycle: Mechanisms of Circulation and Climate in the Tropical Atlantic Sector, Mon. Weather Rev., 112, 1097-1107, doi:10.1175/15200493(1984)112<1097:IVAACM>2.0.CO;2, 1984.

Hoerling, M., Hurrell, J., Eischeid, J., and Phillips, A.: Detection and attribution of 20th century northern and southern African rainfall change, J. Climate, 19, 3989-4008, 2006.

Hu, Z. Z. and Huang, B.: Physical Processes Associated with the Tropical Atlantic SST Meridional Gradient, J. Climate, 19, 5500-5518, doi:10.1175/JCLI3923.1, 2006. 
Hulme, M.: Rainfall changes in Africa: 1931-1960 to 1961-1990, Int. J. Climatol., 12, 685-699, 1992.

Janicot, S., Moron, V., and Fontaine, B.: Sahel droughts and ENSO dynamics, Geophys. Res. Lett., 23, 515-518, doi:10.1029/96GL00246, 1996.

Kalnay E., Kanamitsu, M., Kistler, R., Collins, W., Deaven, D., Gandin, L., Iredell, M., Saha, S., White, G., Woollen, J., Zhu, Y., Cheillab, M., Ebsuzaki, W., Higgins, W., Janowiak, J., Mo, K. C., Ropelewski, C., Wang, J., Leetma, A., Reynolds, P., Jenne, R., and Joseph, D.: The NCEP/NCAP 40-year reanalysis project, B. Am. Meteorol. Soc., 77, 437-470, doi:10.1175/1520-0477(1996)077<0437:TNYRP>2.0.CO;2, 1996 (data available at: http://www.esrl.noaa.gov/psd/data/ gridded/data.ncep.reanalysis.surfaceflux.html).

Kobayashi, S., Ota, Y., Harada, Y., Ebita, A., Moriya, M., Onoda, H., Onogi, K., Kamahori, H., Kobayashi, C., Endo, H., Miyaoka, K., and Takahashi, K.: The JRA-55 Reanalysis: General Specifications and Basic Characteristics, J. Meteorol. Soc. Jpn., 93, 5-48, doi:10.2151/jmsj.2015-001, 2015 (data available at: http://jra.kishou.go.jp/JRA-55/index_en.html\#jra-55).

Lamb, P. J.: Large-scale Tropical Atlantic surface circulation patterns associated with Subsaharan weather anomalies, Tellus, 30, 240-251, 1978.

Lamb, P. J. and Peppler, R. A.: Further Case Studies of Tropical Atlantic Surface Atmospheric and Oceanic Patterns Associated with Sub-Saharan Drought, J. Climate, 5, 476-488, doi:10.1175/1520-0442(1992)005<0476:FCSOTA >2.0.CO;2, 1992.

Li, G., Ren, B., Zheng, J., and Yang, C.: Trend singular value decomposition analysis and its application to the global ocean surface latent heat flux and SST anomalies, J. Climate, 24, 29312948, doi:10.1175/2010JCLI3743.1, 2011.

Lough, J. M.: Tropical Atlantic Sea Surface Temperatures and Rainfall Variations in Subsaharan Africa, Mon. Weather. Rev., 114, 561-570, doi:10.1175/15200493(1986)114<0561:TASSTA>2.0.CO;2, 1986.

Lu, J. and Delworth, T.: Oceanic forcing of the late 20th century Sahel drought, Geophys. Res. Lett., 32, L22706, doi:10.1029/2005GL023316, 2005.

Martin, E. R., Thorncroft, C., and Booth, B. B.: The Multidecadal Atlantic SST - Sahel Rainfall Teleconnection in CMIP5 Simulations, J. Climate, 27, 784-806, doi:10.1175/JCLI-D-13-00242.1, 2014

Marullo, S., Artale, V., and Santoleri, R.: The SST Multidecadal Variability in the Atlantic-Mediterranean Region and Its Relation to AMO, J. Climate, 24, 4385-4401, doi:10.1175/2011JCLI3884.1, 2011.

Munemoto, M. and Tachibana, Y.: The recent trend of increasing precipitation in Sahel and the associated inter-hemispheric dipole of global SST, Int. J. Climatol., 32, 1346-1353, doi:10.1002/joc.2356, 2012.

Omotosho, J. B.: Pre-rainy season moisture build-up and storm precipitation delivery in the West African Sahel, Int. J. Climatol., 28, 937-946, 2008.

Palmer, T. N.: Influence of the Atlantic, Pacific and Indian Oceans on Sahel rainfall, Nature, 322, 251-253, doi:10.1038/322251a0, 1986.

Pan, Y. H. and Oort, A. H.: Global Climate Variations Connected with Sea Surface Temperature Anomalies in the
Eastern Equatorial Pacific Ocean for the 1958-73 Period, Mon. Weather. Rev., 111, 1244-1258, doi:10.1175/15200493(1983)111<1244:GCVCWS>2.0.CO;2, 1983.

Pomposi, C., Kushnir, Y., and Giannini, A.: Moisture budget analysis of SST-driven decadal Sahel precipitation variability in the twentieth century, Clim. Dyn., 44, 3303, doi:10.1007/s00382014-2382-3, 2015.

Rowell, D. P.: Teleconnections between the tropical Pacific and the Sahel, Q. J. Roy. Meteor. Soc., 127, 1683-1706, 2001.

Rowell, D. P.: The Impact of Mediterranean SSTs on the Sahelian Rainfall Season, J. Climate, 16, 849-862, doi:10.1175/15200442(2003)016<0849:TIOMSO>2.0.CO;2, 2003.

Rowntree, P. R.: The influence of tropical east Pacific Ocean temperatures on the atmosphere, Q. J. R. Meteorol. Soc., 98, 290321, doi:10.1002/qj.49709841605, 1972.

Schneider, U., Becker, A., Finger, P., Meyer-Christoffer, A., Rudolf, B., and Ziese, M.: GPCC Full Data Reanalysis Version 6.0 at $2.5^{\circ}$ : Monthly Land-Surface Precipitation from Rain-Gauges built on GTS-based and Historic Data, doi:10.5676/DWD_GPCC/FD_M_V7_250, 2011.

Shinoda, M. and Kawamura, R.: Tropical rainbelt, circulation, and sea surface temperatures associated with the Sahelian rainfall trend, J. Meteorol. Soc. Jpn., 72, 341-357, 1994.

Smith, T. M., Reynolds, R. W., Peterson, T. C., and Lawrimore, J.: Improvements to NOAA's Historical Merged Land-Ocean Surface Temperature Analysis (1880-2006), J. Climate, 21, 2283-2296, doi:10.1175/2007JCLI2100.1, 2008 (data available at: http://www.esrl.noaa.gov/psd/data/gridded/ data.noaa.ersst.v3.html).

Stott, P. A., Gillett, N. P., Hegerl, G. C., Karoly, D. J., Stone, D. A., Zhang, X., and Zwiers, F.: Detection and attribution of climate change: A regional perspective, Wiley Interdiscip. Rev. Clim. Change, 1, 192-211, 2010.

Ting, M., Kushnir, Y., Seager, R., and Li, C.: Forced and Internal Twentieth-Century SST Trends in the North Atlantic, J. Climate, 22, 1469-1481, doi:10.1175/2008JCLI2561.1, 2009.

Tippett, M. and Giannini, A.: Potentially predictable components of African summer rainfall in an SST-forced GCM simulation, J. Climate, 19, 3133-3144, 2006.

Tokinaga, H. and Xie, S. P.: Wave and Anemometer-based Sea Surface Wind (WASWind) for Climate Change Analysis, J. Climate, 24, 267-285, doi:10.1175/2010JCLI3789.1, 2011 (data available at: http://www.dpac.dpri.kyoto-u.ac.jp/tokinaga/waswind.html).

Uppala, S. M., KÅllberg, P. W., Simmons, A. J., Andrae, U., Bechtold, V. D. C., Fiorino, M., Gibson, J. K., Haseler, J., Hernandez, A., Kelly, G. A., Li, X., Onogi, K., Saarinen, S., Sokka, N., Allan, R. P., Andersson, E., Arpe, K., Balmaseda, M. A., Beljaars, A. C. M., Berg, L. V. D., Bidlot, J., Bormann, N., Caires, S., Chevallier, F., Dethof, A., Dragosavac, M., Fisher, M., Fuentes, M., Hagemann, S., Hólm, E., Hoskins, B. J., Isaksen, L., Janssen, P. A E. M., Jenne, R., Mcnally, A. P., Mahfouf, J.-F., Morcrette, J.-J., Rayner, N. A., Saunders, R. W., Simon, P., Sterl, A., Trenberth, K. E., Untch, A., Vasiljevic, D., Viterbo, P., and Woollen, J.: The ERA-40 re-analysis, Q. J. Roy. Meteor. Soc., 131, 2961-3012, doi:10.1256/qj.04.176, 2005 (data available at: http://www.cgd. ucar.edu/cas/catalog/reanalysis/ecmwf/era40/daily_sfc.html).

Wallace, J. M., Mitchell, T. P., and Deser, C.: The Influence of Sea-Surface Temperature on Surface Wind in the Eastern Equatorial Pacific: Seasonal and Interannual 
Variability, J. Climate, 2, 1492-1499, doi:10.1175/15200442(1989)002<1492:TIOSST>2.0.CO;2, 1989.

Willmott, C. J. and Matsuura, K.: Terrestrial Air Temperature and Precipitation: Monthly and Annual Time Series (1950-1999), available at: http://climate.geog.udel.edu/ climate/html_pages/ README.ghcn_ts2.html, 2001.

Wolter, K.: Modes of tropical circulation, Southern Oscillation, and Sahel rainfall anomalies, J. Climate, 2, 149-172, doi:10.1175/1520-0442(1989)002<0149:MOTCSO>2.0.CO;2, 1989.

Wu, R., Kirtman, B. P., and Pegion, K.: Surface latent heat flux and its relationship with sea surface temperature in the National Centers for Environmental Prediction Climate Forecast System simulation and retrospective forecasts, Geophys. Res. Lett., 34, L17712, doi:10.1029/2007GL030751, 2009.
Xue, Y., Smith, T. M., and Reynolds, R. W.: Interdecadal changes of 30-yr SST normals during 1871-2000, J. Climate, 16, 1601-1612, doi:10.1175/1520-0442-16.10.1601, 2003 (data available at: http://www.esrl.noaa.gov/psd/data/gridded/ data.noaa.ersst.v3.html).

Zeng, N.: Drought in the Sahel, Science, 302, 999-1000, 2003.

Zhang, G. J. and Mcphaden, M. J.: The relationship between sea surface temperature and latent heat flux in the equatorial Pacific, J. Climate, 8, 589-605, 1995.

Zhang, R. and Delworth, T. L.: Impact of Atlantic multidecadal oscillations on India/Sahel rainfall and Atlantic hurricanes, Geophys. Res. Lett., 33, L17712, doi:10.1029/2006GL026267, 2006. 